\title{
ANALISIS EFEKTIVITAS KINERJA PENDAPATAN (STUDI KASUS PADA DINAS PARIWISATA DAN KEBUDAYAAN KABUPATEN BOLAANG MONGONDOW TAHUN 2016-2018)
}

\author{
Dhifa N. Buntuan ${ }^{1}$, David P.E. Saerang ${ }^{2}$, Hendrik Gamaliel ${ }^{3}$ \\ 1, 2,3 Jurusan Akuntansi, Fakultas Ekonomi dan Bisnis, Universitas Sam Ratulangi, Jl. Kampus Bahu, Manado \\ 95115, Indonesia \\ E-mail: dhifa_buntuan@yahoo.com
}

\begin{abstract}
In Bolaang Mongondow Regency, locally -generated revenue is still considered low and has not a significant increase. One of the SKPD producing PAD is the Tourism and Culture Office. In 2018, Tourism and Culture Office has not yet reached the target. This study aims to: (1) analyze the causes of revenue realization that does not reach the target, and (2) analyze the effectiveness of revenue performance. The research method used is quantitative descriptive. The type of data used qualitative is an explanation of interviews and quantitative data in a budget realization reports and ticket inventory reports for 2016-2018. Data collection methods used interview and documentation. The results showed, the factors causing the realization of revenue that did not reach the target due to the excessively high income target charged to the Office, while managed revenue sources were very limited. The effectiveness of the performance shows, in 2016 and 2017 are very effective category which reached $113.29 \%$ and $102.93 \%$. While in 2018, included ineffective category that is $69.92 \%$. It is recommended that the Office further optimizes its financial management so that it focuses on adding new tourism objects so that whatever targets are set can be achieved and can increase the effectiveness of its revenue performance.
\end{abstract}

Keywords: effectiveness, revenue, performance, measurement, locally-generated revenue (PAD).

\section{PENDAHULUAN}

Dalam menjalankan otonomi daerah, pemerintah daerah dituntut untuk menjalankan roda pemerintahan yang efektif dan efisien, sehingga mampu mendorong masyarakat untuk berperan serta dalam melaksanakan pembangunan sebagaimana menurut \{UU\} Nomor 33 Tahun 2004 pasal 1 ayat (5) bahwa daerah otonom mengatur dan mengurus urusan pemerintahan masyarakat setempat berdasarkan aspirasi masyarakat. Pemerintah daerah juga dituntut untuk meningkatkan pemerataan dan keadilan, sehingga dapat mengembangkan seluruh potensi yang dimiliki oleh masing-masing daerah sebagaimana tertera dalam $\{U U\}$ Nomor 32 Tahun 2004 pasal 2 ayat (2) bahwa pemerintahan daerah mengurus dan mengatur sendiri urusan pemerintahan.

Sebagai instansi pemerintah yang turut menghasilkan PAD dan salah satu SKPD yang ada di daerah Kabupaten Bolaang Mongondow, Dinas Pariwisata dan Kebudayaan harus dapat mengatur pengelolaan keuangannya dan menggunakan hasil dari pengelolaan tersebut untuk memaksimalkan potensi yang ada. Dinas Pariwisata dan Kebudayaan dipilih sebagai objek karena berdasarkan data yang diperoleh, Dinas Pariwisata dan Kebudayaan termasuk yang belum capai target di tahun 2018. Fakta tersebut menjadi salah satu ketertarikan penulis untuk menganalisis faktor penyebab tidak tercapainya target dan juga mengukur kinerja pendapatannya, bahwa kinerja keuangan pemerintah daerah selalu dikaitkan dengan bagaimana sebuah unit kerja pemerintah daerah atau suatu instansi dapat mencapai tujuan kerja berdasarkan target anggaran yang tersedia Hal ini untuk meningkatkan daya guna dan 
juga hasil guna penyelenggaraan pemerintahan dalam rangka pelayanan terhadap masyararakat dan pelaksanaan pembangunan sesuai dengan peraturan perundang-undangan. Di Kabupaten Bolaang Mongondow, Pendapatan Asli Daerah (PAD) masih dinilai rendah. Ada tujuh SKPD penghasil PAD salah satunya adalah Dinas Pariwisata dan Kebudayaan. Tahun 2018, Dinas Pariwisata dan Kebudayaan termasuk yang belum mencapai target anggaran pendapatan.

\section{TINJAUAN PUSTAKA}

Pengukuran Kinerja Sektor Publik. Mahmudi (2015:6) menjelaskan bahwa pengukuran kinerja merupakan suatu proses penilaian kemajuan pekerjaan terhadap pencapaian tujuan dan sasaran yang telah ditentukan, termasuk informasi atas efisiensi penggunaan sumber daya dalam menghasilkan barang dan jasa, kualitas barang dan jasa, perbandingan hasil kegiatan dengan target, dan efektivitas tindakan dalam mencapai tujuan. Worotikan, Sondakh, dan Gamaliel (2018:547) mengemukakan bahwa kinerja adalah hasil kerja yang dilakukan ooleh seseorang/individu atau kelompok orang untuk melakukan suatu kegiatan secara bertanggungjawab atau sesuai dengan tanggung jawabnya dengan hasil seperti yang diharapkan.

Efektivitas. Efektivitas (hasil guna) adalah ukuran keberhasilan suatu organisasi dalam usaha mencapai tujuan organisasi yang telah ditetapkan. Efektivitas merupakan perbandingan outcome dan output. Outcome merupakan dampak suatu program atau kegiatan terhadap masyarakat sedangkan output merupakan hasil yang dicapai dari suatu program aktivitas dan kebijakan, Mahsun (2006:191).

\section{Efektivitas $=\underline{\text { Realisasi Penerimaan Pendapatan }} \times 100 \%$ \\ Target Penerimaan Pendapatan}

Secara umum, nilai efektivitas pendapatan dapat dikategorikan sebagai berikut:

Tabel 1. Kriteria Efektivitas

\begin{tabular}{lc}
\hline \multicolumn{1}{c}{ Persentase Pengukuran } & Kriteria Efektivitas \\
\hline $100 \%$ Keatas & Sangat efektif \\
$100 \%$ & Efektif \\
$90 \%$ sampai $99 \%$ & Cukup Efektif \\
$75 \%$ sampai $89 \%$ & Kurang Efektif \\
Kurang dari $75 \%$ & Tidak Efektif \\
\hline
\end{tabular}

Sumber: Mahmudi, 2016

Pendapatan. Kieso, Warfield dan Weygantd (2011:955) menyatakan pendapatan adalah arus masuk bruto dari manfaat ekonomi yang diperoleh dari aktivitas normal entitas selama suatu periode. Pendapatan adalah arus masuk harta dari kegiatan perusahaan menjual barang dan jasa dalam suatu periode yang mengakibatkan kenaikan modal yang tidak berasal dari kontribisi penanaman modal. Pendapatan dari kegaiatan perusahaan dagang dasarnya adalah suatu proses mengenai arus penciptaan barang dan jasa oleh perusahaan selama jangka waktu tertentu, (Nafarin, 2006:15).

Pendapatan Asli Daerah. Menurut UU No. 32 Tahun 2004 Pendapatan Daerah adalah hak pemerintah daerah yang diakui sebagai penambah nilai kekayaan bersih dalam periode tahun anggaran yang bersangkutan. Menurut Pratama dan Suartana (2014 : 266), upaya yang dapat dilakukan oleh pemerintah daerah untuk meningkatkan PAD yaitu dengan intensifikasi. Salah satu intensifikasinya adalah dengan menggali sumber-sumber pendapatan baru yang potensinya dimungkinkan untuk dipungut pajak/retribusi. Halim (2004 : 94), 
Pendapatan Asli Daerah adalah penerimaan yang diperoleh daerah dari sumber-sumber dalam wilayahnya sendiri yang dipungut berdasarkan peraturan daerah sesuai dengan peraturan perundang-undangan yang berlaku.

Penelitian Terdahulu. Rukayah, (2017) Penelitian dengan judul Analisis Laporan Realisasi Anggaran Dengan Menggunakan Rasio Efektivitas dan Efisiensi Pada Kantor Badan Perijinan Terpadu dan Penanaman Modal Kabupaten Serang, hasil penelitian menunjukkan rasio efektivitas sebesar $102 \%$ termasuk dalam kategori sangat efektif. Korompot, (2017) Penelitian dengan judul Analysis Of Financial Performance In The Government Of North Sulawesi, hasil penelitian menunjukkan kinerja keuangan dari segi rasio efektivitas termasuk kriteria yang efektif. Rahmawati, (2016) Penelitian dengan judul Analisis Kinerja Anggaran Pendapatan dan Belanja Pada Dinas Perekonomian dan Pariwisata Kabupaten Tuban, hasil penelitian menunjukkan kinerja pendapatan Dinas Perekonomian dan Pariwisata Kabupaten Tuban termasuk kategori baik dari tahun 2013-2015. Sultan, (2016) Penelitian dengan judul Analisis Kinerja Keuangan Pada Dinas Kebudayaan dan Pariwisata Kabupaten Bone, hasil penelitian menunjukkan rasio efektivitas secara keseluruhan belum termasuk dalam kategori efektif dalam memungut Pendapatan Asli Daerah pada Dinas Pariwisata dan Kebudayaan Kabupaten Bone.

\section{METODE PENELITIAN}

Jenis Penelitian. Penelitian ini menggunakan jenis penelitian kualitatif dengan analisis deskriptif. Analisis deskriptif adalah analisis yang dilakukan untuk memaparkan suatu karakteristik tertentu dari sebuah fenomena atas permasalahan yang terjadi.

Waktu Dan Tempat Penelitian. Waktu penelitian dilaksanakan selama bulan Maret hingga Agustus tahun 2019. Penelitian ini bertempat di Kantor Dinas Pariwisata dan Kebudayaan Kabupaten Bolaang Mongondow Jalan Trans Sulawesi Desa Lalow Kecamatan Lolak.

Jenis, Sumber Dan Metode Pengumpulan Data. Jenis data yang digunakan adalah data kualitatif berupa hasil wawancara dengan kepala dinas, bendahara penerimaan, dan staf Dinas Pariwisata dan Kebudayaan Kabupaten Bolaang Mongondow dan data kuantitatif berupa laporan realisasi anggaran dan laporan persediaan karcis selama tahun 2016-2018 yang diperoleh dari data primer, Sedangkan metode pengumpulan data yang digunakan berupa wawancara dan dokumentasi.

Metode Dan Proses Analisis. Metode analisis yang digunakan dalam penelitian ini adalah analisis data deskriptif kuantitatif, penelitian ini menganalisis faktor tidak tercapainya target pendapatan tahun 2018 dan mengukur efektivitas kinerja pendapatan tahun 2016-2018. Berikut ini merupakan susunan proses analisis yang digunakan dalam penelitian :

1. Peneliti mengumpulkan data mengenai penetapan target anggaran pendapatan berupa Laporan Realisasi Anggaran

2. Peneliti mengidentifikasi unsur-unsur yang membentuk PAD Dinas Pariwisata dan Kebudayaan Kabupaten Bolaang Mongondow tahun 2018

3. Peneliti memisahkan data utama dan data pendukung yang didapat dari wawancara dan pengumpulan data kemudian dirangkum serta disajikan dalam bentuk tabel.

4. Peneliti menganalisis penetapan target anggaran dengan melihat dan membandingkan realisasi anggaran tahun 2016-2018

5. Peneliti mengukur efektivitas kinerja pendapatan tahun 2016-2018 dengan menggunakan rasio efektivitas

6. Peneliti menentukan hasil penelitian berdasarkan analisa dari dari data yang telah diperoleh, melakukan penarikan kesimpulan serta verifikasi kembali, penarikan kesimpulan akhir dan memberikan saran yang berkaitan dengan penerapan potongan harga terhadap tingkat penjualan. 


\section{HASIL PENELITIAN DAN PEMBAHASAN}

Gambaran Umum Objek Penelitian. Dinas Pariwisata dan Kebudayaan Kabupaten Bolaang Mongondow dibentuk berdasarkan Peraturan Daerah No. 02 Tahun 2008 Tentang Struktur Organisasi dan Tata Dinas Daerah Kabupaten Bolaang Mongondow. Dinas Pariwisata dan Kebudayaan Kabupaten Bolaang Mongondow adalah unsur pelaksanaan teknis pemerintah daerah di bidang pariwisata, seni dan budaya yang dipimpin oleh Kepala Dinas yang sepenuhnya bertanggungjawab kepada Bupati melalui Sekretaris Daerah dengan memperhatikan petunjuk kebijakan yang bersifat teknis maupun provinsi. Dinas Pariwisata dan Kebudayaan Kabupaten Bolaang Mongondow sangat dibutuhkan oleh masyarakat, khususnya dalam mendukung pembangunan dan pengembangan sektor pariwisata yang secara umum dapat digambarkan sebagai berikut :

a. Terdapatnya objek wisata pemandian air panas dan spa di Desa Bakan dan objek wisata pantai pasir putih maelang

b. Terpeliharanya objek wisata yang dikelola oleh Dinas

c. Tersedianya sarana dan prasarana penunjang pada sektor-sektor pariwisata

d. Tersedianya tenaga kerja yang handal dibidang pariwisata, seni dan budaya

\subsection{Hasil Penelitian}

Faktor Tidak Tercapainya Target Pendapatan Tahun 2018. Berikut ini adalah hasil wawancara yang dilakukan peneliti di Dinas Pariwisata dan Kebudayaan Kabupaten Bolaang Mongondow.

Peneliti : Bagaimana mekanisme penetapan target pendapatan di Dinas Pariwisata dan Kebudayaan Kabupaten Bolaang Mongondow?

Narasumber : Penetapan target pendapatan ditentukan oleh Badan Keuangan Daerah dengan melihat pencapaian realisasi pendapatan untuk tahun-tahun sebelumnya.

Peneliti : Mengapa di tahun 2018 target pendapatan tidak tercapai?

Narasumber : Target pendapatan untuk tahun 2018 tidak tercapai karena terlalu tingginya target yang ditetapkan sedangkan objek wisata yang menghasilkan pendapatan masih kurang.

Peneliti : Ada berapa objek wisata yang menghasilkan pendapatan yang dikelola oleh Dinas?

Narasumber : Sejauh ini, hanya ada satu objek wisata yaitu tempat pemandian air panas jacuzi dan spa yang terletak di Desa Bakan

Peneliti : Bagaimana proses penerimaan atau pendapatan tersebut?

Narasumber : Pendapatan diperoleh dari hasil penjualan tiket oleh petugas dan diserahkan ke bendahara penerimaan Dinas untuk dibuatkan daftar barang persediaan karcis.

Tabel 2. berisi daftar barang persediaan karcis Dinas Pariwisata dan Kebudayaan Kabupaten Bolaang Mongondow tahun 2016-2018.

Tabel 2. Daftar Barang Persediaan Karcis Per 31 Desember 2016

\begin{tabular}{lccc}
\hline \multicolumn{1}{c}{ Jenis / Nama Barang } & Qty & Harga Satuan & Jumlah Harga (Rp) \\
\hline KTM Air Panas Anak-anak & 19600 & 2.000 & $39,200,000$ \\
KTM Air Panas Dewasa & 19900 & 2500 & $49,750,000$ \\
Karcis Parkir Roda 2 & 13000 & 2000 & $26,000,000$ \\
Karis Parkir Roda 4 & 8400 & 2500 & $21,000,000$ \\
\hline
\end{tabular}

Sumber : Dinas Pariwisata dan Kebudayaan Kabupaten Bolaang Mongondo, 2016

Tabel 2. berisi daftar barang persediaan karcis untuk tahun 2016 dengan total penerimaan pendapatan sebesar Rp. 135.950.000. Jumlah karcis terjual sebanyak 60.900. 
Tabel 3. Daftar Barang Persediaan Karcis Per 31 Desember 2017

\begin{tabular}{lccc}
\hline \multicolumn{1}{c}{ Jenis / Nama Barang } & Qty & Harga Satuan & Jumlah Harga (Rp) \\
\hline KTM Air Panas Anak-anak & 7400 & 2.000 & $14,800,000$ \\
KTM Air Panas Dewasa & 6700 & 2500 & $16,750,000$ \\
Karcis Parkir Roda 2 & 3600 & 2000 & $7,200,000$ \\
Karis Parkir Roda 4 & 3200 & 2500 & $8,000,000$ \\
KTM Air Panas Anak-anak & 12500 & 3500 & $43,750,000$ \\
KTM Air Panas Dewasa & 17000 & 4000 & $68,000,000$ \\
Karcis Parkir Roda 2 & 6400 & 3000 & $19,200,000$ \\
Karis Parkir Roda 4 & 5400 & 4000 & $21,600,000$ \\
KTM Bilas & 10600 & 2500 & $26,500,000$ \\
\hline
\end{tabular}

Sumber : Dinas Pariwisata dan Kebudayaan Kabupaten Bolaang Mongondow, 2017

Tabel 3. berisi daftar barang persediaan karcis untuk tahun 2017 dengan total pendapatan sebesar Rp. 225.800.000. Pada tahun ini, terjadi kenaikan harga karcis berdasarkan Perda yang dikeluarkan oleh Bupati. Jumlah karcis yang terjual sebanyak 72.800 .

Tabel 4. Daftar Barang Persediaan Karcis Per 31 Desember 2018

\begin{tabular}{lccc}
\hline Jenis / Nama Barang & Qty & Harga satuan & Jumlah Harga (Rp) \\
\hline KTM Air Panas Anak-anak & 17300 & 3.500 & 60.550 .000 \\
KTM Air Panas Dewasa & 20200 & 4.000 & 80.800 .000 \\
Karcis Parkir Roda 2 & 8100 & 3.000 & 24.300 .000 \\
Karis Parkir Roda 4 & 8100 & 4.000 & 32.400 .000 \\
KTM Bilas & 14300 & 2.500 & 35.750 .000 \\
Sisa Per 31 Desember 2017 & & & 10.950 .000 \\
\hline
\end{tabular}

Sumber : Dinas Pariwisata dan Kebudayaan Kabupaten Bolaang Mongondow, 2018

Tabel 4. berisi daftar persediaan karcis untuk tahun 2018 dengan pendapatan yang diperoleh sebesar Rp. 244.750.000. Jumlah karcis yang terjual yakni sebanyak 68.000.

Penetapan Target Pendapatan. Target pendapatan yang ditetapkan oleh Badan Keuangan Daerah kepada Dinas Pariwisata dan Kebudayaan Kabupaten Bolaang Mongondow setiap tahunnya terus mengalami peningkatan. Tabel. 5. berisi ringkasan anggaran dan realisasi pendapatan Dinas Pariwisata dan Kebudayaan Kabupaten Bolaang Mongondow tahun 2016-2018.

Tabel 5. Ringkasan Anggaran dan Realisasi Pendapatan Dinas Pariwisata dan Kebudayaan Kabupaten Bolaang Mongondow tahun 2016-2018

\begin{tabular}{ccc}
\hline Tahun & Anggaran & Realisasi \\
\hline 2016 & Rp. 120.000 .000 & Rp. 135.950 .000 \\
2017 & Rp. 220.000.000 & Rp. 225.800.000 \\
2018 & Rp. 350.000.000 & Rp. 244.750.000 \\
\hline
\end{tabular}

Sumber : Dinas Pariwisata dan Kebudayaan Kabupaten Bolmong, 2016-2018

Pendapatan tahun 2016 ialah sebesar Rp. 135.950.000 dari target yang sebelumnya diharapkan sebesar Rp. 120.000.000. Tahun 2017 sebesar Rp. 225.000 .000 dari target yang diharapkan sebesar Rp. 220.000.000. Tahun 2018 realisasi pendapatan sebesar Rp. 244.750.000 dari target sebesar Rp. 350.000.000. Pendapatan Asli Daerah merupakan pendapatan yang bersumber dari pemanfaatan potensi sumber daya daerah yang dipungut 
oleh Pemerintah Daerah dalam hal ini adalah objek wisata air panas Desa Bakan yang dikelola oleh Dinas Pariwisata dan Kebudayaan Kabupaten Bolaang Mongondow.

Efektivitas Kinerja Pendapatan. Analisis efektivitas kinerja pendapatan Dinas Pariwisata dan Kebudayaan Kabupaten Bolaang Mongondow tahun 2016-2018 adalah sebagai berikut :

Tabel 6. Ringkasan Laporan Realisasi Anggaran Dinas Pariwisata dan Kebudayaan Kabupaten Bolaang Mongondow Untuk Tahun Yang Berakhir Sampai Dengan 31 Desember 2016

\begin{tabular}{lccc}
\hline \multicolumn{1}{c}{ Uraian } & Anggaran 2016 & Realisasi 2016 & (\%) \\
\hline $\begin{array}{l}\text { Pendapatan-LRA : } \\
\text { Pendapatan Asli Daerah (PAD) - LO }\end{array}$ & $\mathbf{1 2 0 . 0 0 0 . 0 0 0}$ & $\mathbf{1 3 5 . 9 5 0 . 0 0 0}$ & $\mathbf{1 1 3 , 2 9 \%}$ \\
Pendapatan Retribusi Daerah-LRA & & & \\
& 120.000 .000 & 135.950 .000 & $113,29 \%$ \\
Belanja & $\mathbf{3 . 0 6 5 . 8 8 6 . 8 8 6}$ & $\mathbf{2 . 9 3 4 . 4 6 4 . 0 0 2}$ & $\mathbf{9 5 , 7 1}$ \\
& & & \\
Belanja Operasi & 2.596 .587 .174 & 2.489 .504 .290 & 95,88 \\
Belanja Pegawai & 1.587 .676 .286 & 1.535 .857 .050 & 96,74 \\
Belanja Barang dan Jasa & 1.008 .910 .888 & 953.647 .240 & 94,52 \\
Belanja Modal & $\mathbf{4 6 9 . 2 9 9 . 7 1 2}$ & $\mathbf{4 4 4 . 9 5 9 . 7 1 2}$ & $\mathbf{9 4 , 8 1}$ \\
Belanja Modal Peralatan dan Mesin & 268.059 .712 & 249.959 .712 & 93,25 \\
Belanja Modal Gedung dan Bangunan & 115.240 .000 & 115.000 .000 & 99,79 \\
Belanja Modal Jalan, Irigasi dan Jaringan & 6.000 .000 & 0,00 & 0,00 \\
Belanja Modal Aset Tetap Lainnya & 80.000 .000 & 80.000 .000 & 100,00 \\
\hline Sumber : Dinas Parisata
\end{tabular}

Sumber : Dinas Pariwisata dan Kebudayaan Kabupaten Bolaang Mongondow, 2016

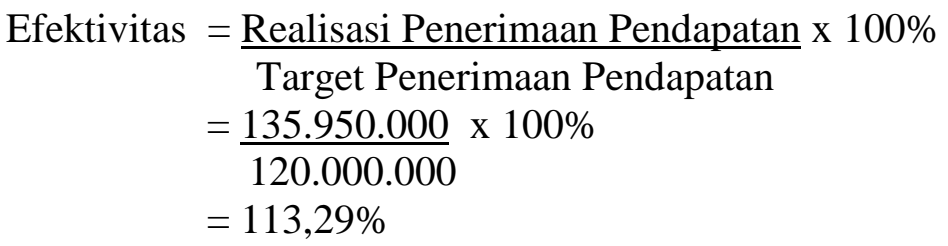

Hasil perhitungan rasio efektivitas pada tahun 2016 adalah 113,29\% artinya sebesar $113,29 \%$ pendapatan telah diterima

Tabel 7. Ringkasan Laporan Realisasi Anggaran Dinas Pariwisata dan Kebudayaan Kabupaten Bolaang Mongondow Untuk Tahun Yang Berakhir Sampai Dengan 31 Desember 2017

\begin{tabular}{lccc}
\hline \multicolumn{1}{c}{ Uraian } & Anggaran 2017 & Realisasi 2017 & $(\%)$ \\
\hline Pendapatan-LRA : & $\mathbf{2 2 0 . 0 0 0 . 0 0 0}$ & $\mathbf{2 2 5 . 8 0 0 . 0 0 0}$ & $\mathbf{1 0 2 , 6 4}$ \\
(PAD) - LO & & & \\
Pendapatan Retribusi Daerah-LRA & 220.000 .000 & 225.800 .000 & 102,64 \\
Belanja & $\mathbf{4 . 2 9 1 . 4 6 9 . 2 8 4 , 2 3}$ & $\mathbf{4 . 1 1 5 . 4 9 1 . 0 1 3}$ & $\mathbf{9 5 , 9 0}$ \\
Belanja Operasi & $2.534 .410 .518,23$ & 2.487 .190 .397 & 98,13 \\
Belanja Pegawai & $1.442 .831 .888,23$ & 1.440 .211 .491 & 99,82 \\
Belanja Barang dan Jasa & 1.091 .578 .630 & 1.046 .978 .906 & 95,91 \\
Belanja Modal & $\mathbf{1 . 7 5 7 . 0 5 8 . 7 6 6}$ & $\mathbf{1 . 6 2 8 . 3 0 0 . 6 1 6}$ & $\mathbf{9 2 , 6 7}$ \\
Belanja Modal Peralatan dan Mesin & 8.758 .766 & 8.258 .766 & 94,29 \\
Belanja Modal Gedung & 1.748 .300 .000 & 1.620 .041 .850 & 92.66 \\
\hline
\end{tabular}

Sumber : Dinas Pariwisata dan Kebudayaan Kabupaten Bolaang Mongondow, 2017

Efektivitas $=\underline{\text { Realisasi Penerimaan Pendapatan }} \times 100 \%$ Target Penerimaan Pendapatan 


$$
\begin{aligned}
& =\frac{225.800 .000}{200.000 .000} \times 100 \% \\
& =102,63 \%
\end{aligned}
$$

Hasil perhitungan rasio efektivitas pada tahun 2017 adalah 102,63\%.

Tabel 8. Ringkasan Laporan Realisasi Anggaran Dinas Pariwisata dan Kebudayaan Kabupaten Bolaang Mongondow Untuk Tahun Yang Berakhir Sampai Dengan 31 Desember 2018

\begin{tabular}{llll}
\hline Uraian & Anggaran 2018 & Realisasi 2018 & $(\%)$ \\
\hline Pendapatan-LRA : & & & \\
(PAD) - LO & $\mathbf{3 5 0 . 0 0 0 . 0 0 0}$ & $\mathbf{2 4 4 . 7 5 0 . 0 0 0}$ & $\mathbf{6 9 , 9 3}$ \\
Pendapatan Retribusi Daerah-LRA & 350.000 .000 & 244.750 .000 & 69,93 \\
Belanja & $\mathbf{4 . 9 6 9 . 9 6 0 . 5 0 4}$ & $\mathbf{4 . 8 5 9 . 1 8 5 . 2 8 9}$ & $\mathbf{9 7 , 7 7}$ \\
& & & \\
Belanja Operasi & 3.462 .068 .504 & 3.361 .359 .289 & 97,09 \\
Belanja Pegawai & 1.701 .767 .125 & 1.670 .485 .379 & 98,16 \\
Belanja Barang dan Jasa & 1.760 .301 .379 & 1.690 .873 .910 & 96,06 \\
Belanja Modal & $\mathbf{1 . 5 0 7 . 8 9 2 . 0 0 0}$ & $\mathbf{1 . 4 9 7 . 8 2 6 . 0 0 0}$ & $\mathbf{9 9 , 3 3}$ \\
Belanja Modal Peralatan dan Mesin & 40.895 .000 & 39.380 .000 & 96,30 \\
Belanja Modal Gedung dan Bangunan & 1.466 .997 .000 & 1.458 .446 .000 & 99,51 \\
\hline
\end{tabular}

Sumber : Dinas Pariwisata dan Kebudayaan Kabupaten Bolmong, 2018

Efektivitas $=\underline{\text { Realisasi Penerimaan Pendapatan }} \times 100 \%$

Target Penerimaan Pendapatan

$$
\begin{aligned}
& =\frac{244.750 .000}{350.000 .000} \times 100 \% \\
& =69,92 \%
\end{aligned}
$$

Hasil perhitungan rasio efektivitas pada tahun 2018 adalah 69,92\%. Artinya sebesar $69,92 \%$ pendapatan telah diterima

\subsection{Pembahasan}

Faktor Tidak Tercapainya Pendapatan. Penelitian Dinas Pariwisata dan Kebudayaan Kabupaten Bolaang Mongondow tidak mencapai target di tahun 2018 karena terlalu tingginya target anggaran pendapatan yang dibebankan kepada Dinas Pariwisata dan Kebudayaan Kabupaten Bolaang Mongondow, sementara dana yang tersedia untuk pengembangan objek wisata masih kurang. Target anggaran yang ditetapkan terbilang tinggi karena berdasarkan tahun-tahun sebelumnya, Dinas Pariwisata mampu untuk mencapai target anggaran pendapatan lebih dari $100 \%$.

Tabel 9. Tabel Ringkasan Anggaran dan Realisasi Pendapatan Dinas Pariwisata dan Kebudayaan Kabupaten Bolaang Mongondow tahun 2016-2018

\begin{tabular}{cccc}
\hline Tahun & Anggaran & \multicolumn{1}{c}{ Realisasi } & \multicolumn{1}{c}{$(\%)$} \\
\hline Pendapatan-LRA : (2016) & 120.000 .000 & 135.950 .000 & $113,29 \%$ \\
Pendapatan-LRA : (2017) & 220.000 .000 & 225.800 .000 & 102,64 \\
Pendapatan-LRA : (2018) & 350.000 .000 & 244.750 .000 & 69,93 \\
\hline
\end{tabular}

Sumber : Dinas Pariwisata dan Kebudayaan Kabupaten Bolmong, 2016-2018

Pendapatan tahun 2016 ialah sebesar Rp. 135.950.000 dari target yang sebelumnya diharapkan sebesar Rp. 120.000.000. Tahun 2017 sebesar Rp. 225.800.000 dari target yang diharapkan sebesar Rp. 220.000.000. Tahun 2018 realisasi pendapatan sebesar Rp. 244.750.000 dari target yang diharapkan sebesar Rp. 350.000.000. Jika dibandingkan dengan 
tahun sebelumnya, pendapatan untuk tahun 2018 mengalami kenaikan sebesar Rp. 18.950.000. Hal ini menunjukkan bahwa kemampuan Dinas Pariwisata dan Kebudayaan dalam menghasilkan PAD cukup baik, hanya saja tidak mencapai target sesuai target anggaran yang telah ditetapkan. Salah satu yang termasuk dalam prinsip penganggaran diantaranya adalah disiplin anggaran. Artinya bahwa pendapatan yang direncanakan merupakan prakiraan yang terukur secara rasional yang dapat dicapai untuk setiap sumber pendapatan. Pada kenyataanya, sumber pendapatan Dinas Pariwisata dan Kebudayaan Kabupaten Bolaang Mongondow hanya terdapat satu objek wisata yaitu wisata air panas dan spa Desa Bakan.

Efektivitas Kinerja Pendapatan. Penelitian dari Pangkey (2015) dengan judul Analisis Efektivitas dan Efisiensi Anggaran Belanja Pada Dinas Kebudayaan dan Pariwisata Provinsi Sulawesi Utara menunjukkan tahun 2010-2014, penggunaan anggaran belanja langsung keseluruhannya tidak efektif karena banyak program yang terealisasi tidak sesuai dengan anggaran yang direncanakan. Sedangkan penelitian dari Tantri (2018) dengan judul Analisis Kinerja Anggaran Belanja Dinas Kebudayaan Daerah Istimewa Yogyakarta Tahun 2012-2016 menunjukkan rasio efektivitas belanja tidak langsung sudah berjalan secara efektif. Berkaitan dengan pengukuran kinerja pendapatan, diketahui bahwa pada tahun 2016, rasio efektivitas pendapatan adalah sebesar 113,29\%, tahun 2017 sebesar 102,63\%. Hal ini menunjukkan kinerja pendapatan Dinas Pariwisata dan Kebudayaan Kabupaten Bolaang Mongondow untuk tahun 2016-2017 termasuk dalam kategori sangat efektif karena melebihi angka 100\%. Oleh karena pencapaian realisasi pendapatan tahun 2016 dan 2017 sangat efektif, maka menjadi dasar penetapan target anggaran pendapatan di tahun berikutnya. Pendekatan sistem penganggaran dilaksanakan berdasarkan penganggaran berbasis kinerja (performance based budgeting) yang mengutamakan upaya pencapaian hasil kerja (output) dan dampak (outcome) sesuai dengan sasaran/target yang hendak dicapai. Sementara, tahun 2018 rasio efektivitas pendapatan adalah sebesar 69,93\% termasuk dalam kategori tidak efektif karena pendapatan yang terealisasi kurang dari 75\%. Hal ini sejalan dengan penelitian yang dilakukan oleh Sari (2018) dengan judul Analisis Efektivitas dan Efisiensi Pelaksanaan Anggaran Belanja pada Bappeda Kota Samarinda yang menunjukkan tingkat efektivitas tahun 2011-2015 cukup bervariasi. Rasio efektivitas tertinggi pada tahun 2014 dan terendah tahun 2013. Sebaiknya, Dinas Pariwisata dan Kebudayaan Kabupaten Bolaang Mongondow harus menggali lagi potensi yang ada di Kabupaten Bolaang Mongondow, serta lebih memaksimalkan dan mengoptimalkan pengelolaan dananya agar fokus menambah objek wisata baru yang dapat meningkatkan PAD. Sehingga berapapun target yang ditetapkan oleh Pemerintah Daerah bisa tercapai.

\section{KESIMPULAN DAN SARAN}

\subsection{Kesimpulan}

Berdasarkan hasil penelitian dan pembahasan pada penelitian ini, dapat ditarik kesimpulan sebagai berikut :

1. Penetapan target anggaran pendapatan tahun 2018 yang terlalu tinggi menyebabkan tidak tercapainya realisasi pendapatan di Dinas Pariwisata dan Kebudayaan Kabupaten Bolaang Mongondow. Sementara, objek wisata yang dikelola oleh Dinas Pariwisata dan Kebudayaan Kabupaten Bolaang Mongondow masih kurang. Dana pembangunan objek wisata juga masih minim.

2. Hasil analisis kinerja pendapatan Dinas Pariwisata dan Kebudayaan Kabupaten Bolaang Mongondow ditinjau dari segi efektivitas untuk tahun 2016 dan 2017 termasuk dalam kategori yang sangat efektif yakni mencapai $113,29 \%$ untuk tahun 2016 dengan kenaikan pendapatan sebesar Rp. 15.950.000, dan tahun 2017 rasio efektivitas menunjukkan hasil 102,93\% dengan kenaikan pendapatan sebesar Rp. 


\subsection{Saran}

5.800.000 dari target yang ditetapkan. Tahun 2018 termasuk dalam kategori tidak efektif yaitu sebesar 69,92\% artinya mengalami penurunan sebesar Rp. 105.250.000 dari target anggaran yang ditetapkan.

Berdasarkan hasil penelitian dan pembahasan maka saran yang diberikan peneliti adalah sebagai berikut :

1. Dinas Pariwisata dan Kebudayaan Kabupaten Bolaang Mongondow harus lebih memaksimalkan dan mengoptimalkan pengelolaan keuangannya agar fokus menambah objek wisata baru yang dapat meningkatkan PAD sehingga berapapun target yang ditetapkan oleh Pemerintah Daerah bisa tercapai.

2. Dinas Pariwisata dan Kebudayaan Kabupaten Bolaang Mongondow lebih menggali lagi potensi wisata yang ada di Kabupaten Bolaang Mongondow untuk menambah pendapatan sehingga target anggaran yang ditetapkan Pemerintah Daerah akan bisa tercapai.

3. Bagi peneliti selanjutnya untuk bisa menambahkan rasio - rasio keuangan yang lain, seperti rasio efisiensi.

4. Penulis hanya memasukkan data tahun 2016-2018. Dikiranya supaya peneliti selanjutnya bisa menambahkan data tersebut.

\section{DAFTAR PUSTAKA}

Halim, A. (2004). Akuntansi Keuangan Daerah. Yogyakarta : UPP AMP YKPN.

Mahmudi. (2015). Manajemen Kinerja Sektor Publik. Edisi Ketiga. Yogyakarta : UPP STIM YKPN.

Mahsun, M. (2006). Pengukuran Kinerja Sektor Publik. Edisi Pertama. Yogyakarta : BPFE.

Mahmudi. (2016). Akuntansi Sektor Publik. Edisi Revisi. Yogyakarta : UII PRESS.

Kieso, D. E., Weygandt, J. J., Warfield, T. D. (2011). Akuntansi Intermediate. Edisi Ketujuh belas. Jilid Dua. Diterjemahkan oleh Emil Salim. Jakarta : Erlangga.

Korompot, R. (2017). Analysis of Financial Performance in the Government of North Sulawesi. Journal Accountability, 8(2). 9-19. Retrived from https://ejournal.unsrat.ac.id >index.php> accountability > article > view

Nafarin. (2006). Penganggaran Perekenomian. Edisi Ketiga. Jakarta : Salemba Empat.

Pangkey, I., dan Pinatik, S. (2015). Analisis Efektivitas dan Efisiensi Anggaran Belanja Pada Dinas Kebudayaan dan Pariwisata Provinsi Sulawesi Utara. Jurnal EMBA. 3(4), 3343. Retrived

from https://ejournal.unsrat.ac.id/index.php/emba/article/view/10581/10168

Pratama, I. P., dan Suartana, I. W. (2014). Perbandingan Tingkat Efisiensi dan Efektivitas Penerimaan Pajak Hiburan Dinas Pendapatan Kota Denpasar dan Kabupaten Badung. E-Jurnal Akuntansi Universitas Udayana. 7(2), 266-279. Retrived from https://ojs.unud.ac.id/index.php/Akuntansi/article/view/8831

Rahmawati, R. D. (2016). Analisis Kinerja Anggaran Pendapatan Dan Belanja Daerah Pada Dinas Perekonomian dan Pariwisata Kabupaten Tuban. Skripsi. Sekolah Tinggi Ilmu Ekonomi Perbanas, Surabaya. Retrived from http://eprints.perbanas.ac.id/1019/

Rukayah, Kusumawati, N., dan Raden, I. A. (2017). Analisis Laporan Realisasi Anggaran dengan Menggunakan Rasio Efektifitas dan Efisiensi Pada Kantor Dinas Perijinan Terpadu dan Penanaman Modal Kabupaten Serang. Jurnal Akuntansi. 4(2), 38-43. Retrived from http://e-jurnal.lppmunsera.org/index.php/Akuntansi/article/view/246 
Sari, D. N., Mintarti, S., dan Pattisahusiwa, S. (2018). Analisis Efektivitas dan Efisiensi Pelaksanaan Anggaran Belanja. Jurnal FEB, 15(1). Retrived from http://journal.feb.unmul.ac.id/index.php/KINERJA/article/view/4051

Tantri, S. N., dan Irmawati, P. (2018). Analisis Kinerja Anggaran Belanja Dinas Kebudayaan Daerah Istimewa Yogyakarta Tahun 2012-2016. Jurnal Akuntansi Terapan Indonesia. 1(1), 27-37. Retrived from http://journal.umy.ac.id/index.php/jati/article/view/3815

Undang - Undang Republik Indonesia Nomor 32 Tahun 2004 Tentang Pemerintahan Daerah. Jakarta.

Worotikan, J. H., Sondakh, J. J., dan Gamaliel, H. (2018). Analisis Laporan Akuntabilitas Kinerja Instansi Pemerintah Pada Dinas Pekerjaan Umum Kabupaten Minahasa. Jurnal Riset Akuntansi Going Concern. 13(4), 546-555. https://doi.org/10.32400/gc.13.04.21431.2018 